\title{
Research on E-banking Functionality and Technology Empowerment in Palestine: An Empirical Investigation
}

\author{
Shadi Emad Areef Alhaleh Ph. D ${ }^{1^{*}}$ Dr. Puji Handayati ${ }^{*}$, Prof., Dr. Hua Wang ${ }^{3^{*}}$
}

${ }^{1}$ Department of Accounting Management, University of Economic and Law, China

${ }^{2}$ Department of Accounting, State University of Malang, Indonesia

${ }^{3}$ Department of Accounting Management, University of Economic and Law, China

*Corresponding E-mail:shadilahaleeh@gmail.com,puji.handayati.fe@um.ac.id,onlywh@163.com

\begin{abstract}
This study made in order to diagnose the customers' perspective towards the acceptance and implementation of new updated e-banking system in Palestine, and analyze the impact of e-banking on users who are intended to adopt technological banking technique. Dramatically, this study focused on the advantages, benefits, and tasks of e-banking through examining the factors which contributes and enhances the adoption of e-banking in Palestine. A purposive sampling technique (selective or subjective sampling) was employed to recruit 84 customers representing the desired range of demographic characteristics (e.g. gender, age, computer use, and internet accessibility), prior online experiments, and their educational level.

The findings of this research showed that the implementation of e-banking (Perceived usefulness (PU), Perceived Ease of use (PEOU), Perceived IT Beliefs (PITB), and Task-Technology Fit (TTF) has a positive influence on Palestinian Commercial and Islamic Bank customers' intention. Value research which has a practical contribution of this work would provide new guidelines and basics on E-banking, especially related to Palestine, which has a relative dearth of literature on the implementation of E-banking, and provide some insights into the role of this technique to make a substantial difference, thereby it could be used to enhance an appropriate and good improvements of e-banking in Palestinian's banks. Thus, this would lead to help banks shift gradually from the traditional way of banking into delivery of its products and services electronically.
\end{abstract}

Keywords: E-banking, Acceptance of Technology, Customers' intention, Palestinian's banks

\section{INTRODUCTION}

One of the methods and techniques which are most widely applied lately in financial service institutions is an electronic banking or online banking. This technique has been adopted and used in the mid-1990s, therefore gradually becoming more important to be used in banking sector (Allen et al, 2001). The term electronic banking refers to the provision, accessibility, and availability of information or services offered by a bank to customers, via computer, and phone app or television (Allen et al, 2001). Nowadays, the necessity of E-banking requires that, banks' managers and employees should focus on providing new technological system that could improve the effectiveness and efficiency of the operating banks' services in order to serve a wide variety of customers. Unfortunately, the abilities, skills, experiences, and empirical evidence of customers intention to implement e-banking in Palestine is still lack.

Thus, this study made in order to diagnose the customers perspective towards the acceptance and implementation of new updated ebanking system in Palestinian banks located in the 
west-bank. Currently, the need for e-banking is increasingly growing day by day, because it allows customers to conduct financial transactions easily and conveniently and increase their satisfaction, allows unlimited transfer at no cost and mobility in operations, and contributes to the improvement of banks quality as well. Thus, the implementation of e-banking is more effective than traditional banking methods which relayed on filling papers, storing checks, withdrawals and cash handling, and loan applications in which those traditional ones were noticed by both customers and banks, and they are usually done manually at those traditional banks. Therefore, the manual processes of traditional banks are usually charged with higher costs and it could be a huge task for it. Moreover, the use of e-banking system helps banks execute all financial transactions easily, and store customers' financial information and other data as quick as possible compared to traditional banks, therefore this will lead to reduce banking costs in general. The main reason for the adoption of E-banking is the reduction of transaction processing cost and time savings (Nehmzow, C. 1997).The establishment of e-banking systems has been used as a measurable instrument to differentiate among countries so as to discover the strengths and weaknesses points of each system. Moreover, e-banking systems could be successfully installed and implemented if there is a well-managed strategy adopted by banks' managers and employees to improve the quality of the system. In fact, creating effective database, and increasing the awareness of employees and customers towards e-banking systems could lead to upgrade the ability and the acceptance of the system as well as the electronic process of data (input, processing, storing, transmitting, receiving, and output) will be run smoothly and easily.

Thus, the access to customers' data will be no longer restricted. Recently, e-banking system has been considered as a key player that is used to connect all customers electronically in order to allow them accessing into their accounts easily, keep them communicating with the system, and provide them with new updates of the system, meanwhile the role of information technology (IT) is used to enhance productivity, new system usefulness perception, security, privacy, design, and the content of e-banking system. Therefore, more developed service is one that provides customers with the opportunity to gain an access to their accounts and execute transactions or to buy product online by via internet (Daniel, 1999). With the population of approximately 6 million in Palestine (Palestinian Central Bureau of Statistics, 2018), it is vital for bankers to understand the current usage trend of e-banking system. Taking into account, the development of e-banking system could be affected by many factors, including social cultural, tradition, education (Herve, J. 2013), economic such as economic system, average income level (Meshkany, F. A., 2013), and technological such as industrial infrastructure, technologic background (Parhizgar, M. M., 2014), and other considerations.

This study analyzes and examines the factors which contributes and enhances the adoption of e-banking in Palestine, and the impact of e-banking implementation on the performance and quality of Palestinian banks in which these factors are: the perceived ease of use (PEOU), the perceived usefulness (PU), the perceived information technology beliefs (PITB), Tasktechnology fit (TTF), intention of use (INT). This study will be measured by different demographic characteristics, such as different age groups, educational level, income level and etc. It is anticipated that this study will add to the body of knowledge on e-banking systems functionality, especially as it relates to Palestine, which has a relatively dearth of literature on e-banking systems, and provide clear insights into banking sector operating in Palestine, which is the primary motivation of this study.

The result of this study are useful for the banking sector in formulating rational decisions, and appropriate strategies to build customer satisfaction, and create positive relationships with them. Furthermore, the study objective is to test and analyze the hypothesis to figure out the customer perspective towards the implementation of e-banking. In addition, this study is pretty rational in terms of providing new ground theories, so that, the intended role is to give insight that would be useful in relation to other interventions for E-banking system and Technology acceptance in Palestine, and improve the knowledge about the importance of acquiring new E-banking technological systems, and its role to improve the quality of bank services and performance. Therefore, this would be a useful resource and 
beneficial to customers, employees, administrators, and the government as well. Additionally, this study is justified on the grounds that provides a recommendation for further studies on Analysis of E-banking implementation and technology acceptance in Palestinian Banks. Consequently, the theoretical part of the study will provide empirical evidence of customers towards the implementation of E-banking system in Palestinian banks, including Theory of Accepted Model (TAM) and Task-Technology Fit (TTF). Meanwhile, the practical contribution will provide new guidelines and basics that could be used to enhance an appropriate and good improvements of e-banking in Palestinian banks. Thus, this would lead to help banks shift gradually from the traditional way of banking into delivery of its products and services electronically.

\subsection{Research focus}

This study made to focus on:

Understanding the E- banking implementation system and the acceptance of Technology in Palestinian banks, analyzing the advantages and transactions of E-banking system, and providing

\section{LITERATURE REVIEW}

\subsection{Definition of the E-banking}

The definition of e-banking has been explained in different ways. Daniel (1999) defined e-banking as the electronic delivery of new and traditional banking products and services directly to customers through updated, and automated interactive communication channels, therefore those communication channels could be adopted through different terminal devices such as cell phone, bank's website, and desktop software in which this could lead to facilitate a wide variety of customers, and make their access into their accounts as fast as possible. Pikkarainen, et. al (2004) defined an internet banking as an electronic gate that could enable customers using different types of banking services and products ranging from bill payment to making investments' decisions. With the exception of cash withdrawals, e-banking could provide customers with different operations to make their access easily into the clear clarification on the importance of e-banking services, and its useful and trustworthy role to serve the Palestinian community as easily as possible. In addition, this study has focused on analyzing and testing hypotheses that have a deep relation with content of this study, these factors are set as follows: the perceived ease of use (PEOU), the perceived usefulness (PU), and the perceived information technology beliefs (PITB), Tasktechnology fit (TTF), intention of use (INT).

\subsection{Research questions}

1. What factors which constitute e-banking functionality in the Palestinian banks?

2. Is there any impact of E-banking on customer Attitude, behavior, and intention to use (INT)?

\subsection{Research objectives}

1. To reveal the adoption of e-banking mentioned factors in Palestinian banks.

2. To determine which factor that has a substantial impact on customers' intention of e-banking in Palestinian banks.

3. To examine the effect of e-banking on customers attitude, and behavior.

system, therefore customers can do any financial transaction at the click of a mouse (DeYoung, 2001). In fact, e-banking is such an effective tool that should be adopted by, and implemented in Palestine and other developing countries, because it has a substantial impact on the performance and the quality of banks financial transactions, products and services, and it gives a clear image to customers and employees as well about its effective operations. Additionally, many advantages to banks offered by e-banking such as reduction in cost of transaction, easy to make utility payments, more effective marketing and communication at lower costs, online services promotion and purchases, pay bills online by saving postal services, mass customization to suit the likes of each user, and innovation of new products and services, (Tuchilla, 2000). The adoption of e-banking strategy could be a beneficial method, because it is considered as a better or quicker response to the technological changes, and wholly market evolution (Jayawardhena and Foley, 2000). Eventually, 
internet banking has been classified as the most effective factor in the business economy today.

\subsection{Technology Acceptance Model (TAM)}

This model proposed originally by Fred Davis in 1989. TAM is considered as a primary instrument that diagnoses and examines the usage, benefits, performance, and the adoption of E-banking. Additionally, TAM technique has also been used to discover the most influencing factors that could affect computer software applications acceptance (Kazi, A. K., \& Mannan, M. A. 2013). Thus, TAM gives an important clarification and reasons for unacceptable systems in society (Fred Davis, 1989). Moreover, the determinants of TAM have been considered as a measurable tool for different business activities and operations, due to the fact that the model has an influential theoretical basis and sufficient empirical support. When it is used effectively, the model can save an educational institution from the risk of investing in a technology that may remain abandoned or grossly underutilized. However, the things that should be noticed is there is an overwhelming need to acquire and adopt TAM in different economic and business sectors, because the power of this model has been derived from the real existence of theoretical assumption and practical effectiveness.

TAM has been improved and developed to address customers or users willingness to accept and use new technology or media in the field of Ebanking products and services. Davis, et. al. (1989), indicated that the behavioral beliefs and outcome evaluation could not accurately measure an individual's acceptance of a new system as they are much influenced by various external factors, therefore, the perceived ease of use and usefulness are considered as the most two influential variables that affect the shape of users' attitudes and behavioral intention (Davis. 1989; Pavlou. 2003). Technology acceptance model has been perfectly applied to serve a wide range of empirical researches, reports and studies, because the model has a strong impact on the quality and performance of businesses, in which the model has also been used to predict and explain acceptance and adoption of a variety of technologies electronic banking, mobile education, and social networks. This study has used technology acceptance model in order to obtain results and conclusions about customers' intention to use new technology or service in the field of Palestinian banks, in addition, the study will discover whether e-banking is a beneficial tool to be applied instead of traditional methods or not. Arguments that TAM is an acceptable model and has been employed in many information technology and information system areas such as e-learning, World-Wide-Web, online auctions, Radio Frequency Identification (RFID), e-portfolio systems, wireless LAN, E-government, Ecommerce, internet banking, and mobile learning (Almasri. 2014). Alharbi and Steve (2014) supported that TAM has been adopted and tested as a useful framework in the field of information science and Learning Management Systems.

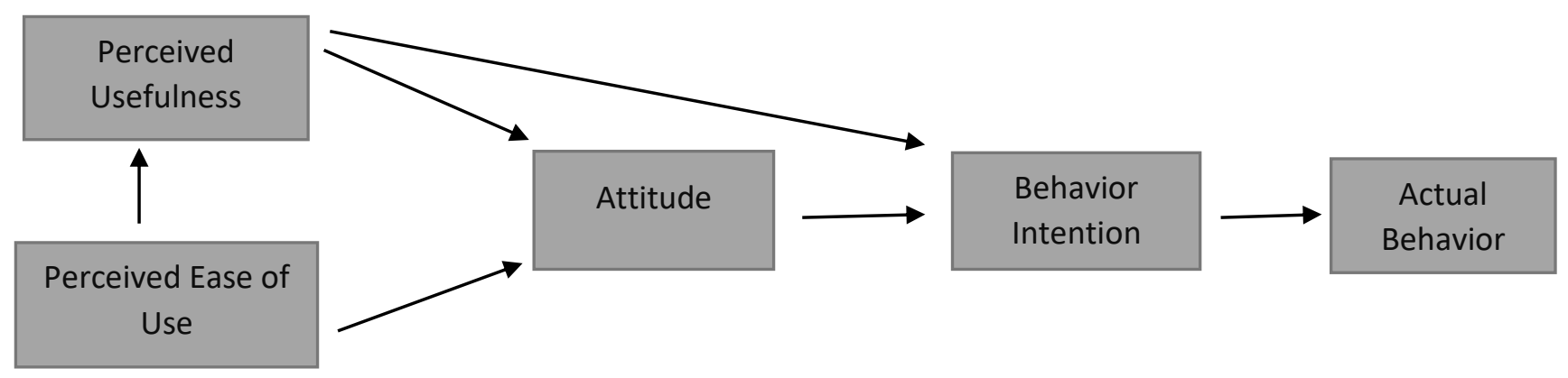

Source: Technology Acceptance Model by Davis (1989) 


\subsection{The perceived information technology beleifs (PITB)}

The studies in Management Information System (MIS) found that the factor of the perceived beliefs incompatibility, image, and trialability of an innovation are the key factors in the technology adoption of the behavior (Davis et al, 1989). Compatibility is seen as the capability of an innovation to be consistent with the person values, desires, and bygone experiences of potential adopters. Parhizgar and Poursaleh, found that perception of compatibility shown as the main interpreter of innovative use. This factor has relation with TAM. It explains the ability of information technology to give clear image or bring the most realistic outcomes, and the effective role in the social system, and it also reflects the customers' perception towards e-banking. Furthermore, the perceived IT beliefs is always measured by the willingness of customers who want to use new innovative technique that could make the process and the services of banks to be run more conveniently and smoothly. Thus, IT beliefs could be acquired through reinforcing and strengthening the most qualified innovative system, therefore, this will lead to increase the confidence and satisfaction of using e-banking by customers. Many studies and reports have supported that, the perceived IT beliefs has a positive significant on customers' attitude, and it has a strong impact on removing all doubts, misunderstanding about the trust ability of the ebanking system. Thus, this variable has been selected by the researcher to obtain any substantial impact on the intention to use of e-banking in Palestinian banks.

\subsection{Perceived Usefulness (PU) on employee Attitude of E-banking system}

According to Davis, et. al (1989), perceived usefulness is as a level of a person believes in the usefulness of a particular system to advance their performance. This study has taken into account two determinants in order to enhance the perceived usefulness. Firstly, privacy which examines the influence on customers' desire to engage in online e-banking services, activities, and financial exchanges and other transactions, in addition to storing sensitive personal information in the system. Moreover, does privacy of the system could help customers easily trust ebanking on the behalf of usefulness? Secondly, Design which examines the convenience and easy access to the system, the design of electronic system plays an important role to enhance the perceived usefulness. Furthermore, the design of a good system could enable a wide a variety of customers engaging as easily as possible into the system. Thus, the design could provide clear insights and feedback whether customers satisfied with the design of the system. Proctor, et. al (2002, 2003) discussed content preparation in a broad sense and identified its four aspects: knowledge elicitation, information organization and structure, information retrieval, and information presentation. Moreover, Davis, F. D. (1989) reported that for banks the degree of perceived usefulness of internet banking is a key factor to promote consumer use as well from the finding supports. Hence, it is hypothesized that perceived usefulness of internet banking has a positive effect on customer attitud and intention to use e-banking products and services. Based on prior reports, and published studies, the perceived usefulness has been emerged from the main components of ease of navigation; efficiency; flexibility, reliability, personalization, responsiveness, assurance/trust, and price knowledge (Herve, J. 2013).

\subsection{Task-Technology Fit (TTF)}

According to (Goodhue), the task-technology fit model gives clarifications on, and expands the TAM by taking into account whether the task affects uses. Genuinely, task-technology fit model used to provide guidelines on the implementation of new adopted technology, and it emphasizes on the availability and accessibility of output. Furthermore, TTF is usually measured by individuals who are intended to fulfill their different jobs, and activities electronically, and perform too many transaction online. Furthermore, TTF model is seeking to know whether the technology fits a wide range of customers' requirements, therefore, the 
technology will be used as tool that links different customers with different activities in the same time, meanwhile tasks will be considered as the actions of turning inputs into outputs conducted by customers. In the context of e-banking, tasktechnology fit refers to the convenience, content, and the ability of technology to assist a wide variety of users in performing their operational activities unrestrictedly. Specifically, this model has been used to match between users and their tasks, and it interprets that the higher the fit degree, the better the performance may result. Moreover, Goodhue (1995) has adopted new method that could be used to support the process of decision making, therefore this method has been used to focus on client domain of IT. Based on this domain, the TIF model has been considered as a tool that could perform different tasks, and it might include: 1) defining required data, 2) analyzing and accessing data, and 3) clarifying and interpreting the access of data. Particularly, banks' customers would like to choose and adopt a well-recognized technological techniques that could enable them to make their tasks with the most net benefit. On other hand, technological techniques that don't offer sufficient benefits will never be used. Simply, task technology fit should be a model that could meet the whole requirements of new customers in which this could improve the quality of the used technology of e-banking, and would give a good image to those who are intended to use it.

\subsection{Attitude towards Intention (INT) to Use E-banking system}

According to customer perception, it finds out that there is a well-collaborated relation between ebanking system and intention to use e-banking system. Attitude is a key player that clarifies the human behavior intention to use e-banking services (Goodhue, D. L., 1995). Intention (INT) to use internet banking system has been used to predict the acceptance of customers to use information system in Palestinian banks as well as used to determine whether customers are willing to adopt and implement e-banking system rather than keep on using traditional manual procedures. In general, the intention of adoption new technology may be defined as a formal communication between customers and their work tasks, concerning the evaluation of internet banking services and it has been considered to be one of the most powerful forces in the Palestinian banks. To be precise, the importance of customer choice to adopt a new technological service is usually influenced by a well-managed intention, especially when they have obtained benefits of using it. This is explained due to the fact that customers prefer to rely on secure system which assist them in updating and managing their actions, and work tasks easily and conveniently. The contributions of this study are Theoretical, first, it provides empirical evidence of the perceived on customer implementing of Ebanking system in Palestinian banks. Second, as theoretical models used, it will be first study using two most important models relating IT adoption which are Technology acceptance model (TAM) and Task Technology fit (TTF) combined both additional perceived IT beliefs. The practical contribution is to improve the management skills and capacities of Palestinian banks, research is expected to identify ways of adopting a strong internet banking services that would change and remove any unpredictable obstacles that could hamper the development of e-banking system in Palestine. This work seeks to clarify the use of Ebanking system on service delivery and it would be of great significance to the banks, the regulatory bodies, and the consuming public and to the business world at large in Palestine. In addition, the study assumes that by raising the awareness of users about the importance of ebanking in Palestinian banks, then the procedures to implement these systems will be easy. For future researchers, the result of this study expected to be material and a reference to conduct research in e-banking, especially with regard to the accomplishment of the desirable purposes of e-banking system and the reduction of higher costs resulting from traditional banking methods. 


\section{RESEARCH METHOD}

\subsection{Population and Sample}

A multiple regression modeling approach was proposed as an effective method for studying the relationships between dependent variable and independent variables. This study population will include all the banks that are operating in Palestine and registered with the authority of Palestinian monetary. There are 16 commercial banks and 3 Islamic banks operating in Palestine (Palestinian monetary authority, 2018). The research population consists of the customers who have an account at any commercial banks and Islamic banks in the State of Palestine. Therefore, all respondents have been called and invited to participate in the research survey. Since all their headquarters are located in Palestine (West-Bank District), the whole population was invited to participate in the survey. Hence, the researcher has distributed 140 questionnaires, yielding a response rate of $60 \%$, and those questionnaires have been transferred, and handled to each respondent in terms of demographic characteristics in order to ensure the validity and reliability of the research.

\subsection{Data Collection}

The research questionnaire was designed based on previous empirical literature. The questionnaire design was pre-tested and redesigned through personal interviews with banks' managers and banks' customers by undertaking the pilot study work (Aaker et al, 2001). The research questionnaire has been used as primary data collection method. The components of e-banking and acceptance technology model items were measured and tested by Likert- scale ranging from 5 points which starts from (strongly agree) to 1 (strongly disagree). For the e-banking and intention, and attitude of customers dimensions, the research respondents were asked to indicate the degree of agreement or disagreement on the ebanking items that banks used e-banking technique in order to achieve customer intention. Based on the literature of this study, the scale items was selected according to the proposed hypotheses, the following are the research hypotheses in the context of the implementation of e-banking and technology acceptance in Palestinian banks. The independent variables involve Perceived usefulness (PU), Perceived Ease of use (PEOU), Perceived IT Beliefs (PITB), and Task-Technology Fit (TTF) through Attitude of using e-banking system and dependent variable Intention to use E-bank system. Based on most non-probability sampling methods are conveniences sampling which involves sample members who can provide the required information and who are more available to participate in the study.

A purposive sampling technique (selective or subjective sampling) was employed to recruit 84 customers representing the desired range of demographic characteristics (e.g. gender, age, computer use, and internet accessibility), prior online experiments, and their educational level. Therefore, the number of customers who are considered as a representative sample is 84 customer. Slovin formula used to determine the representative samples with the error rate $5 \%$. Slovin formula: $n=N /(1+N$ (e) 2).

For the model test, all constructs modeled are as reflective and predictive.

TAM has been disclosed, and represented by INT in order to clarify the relationship between variables. The equation is described below:

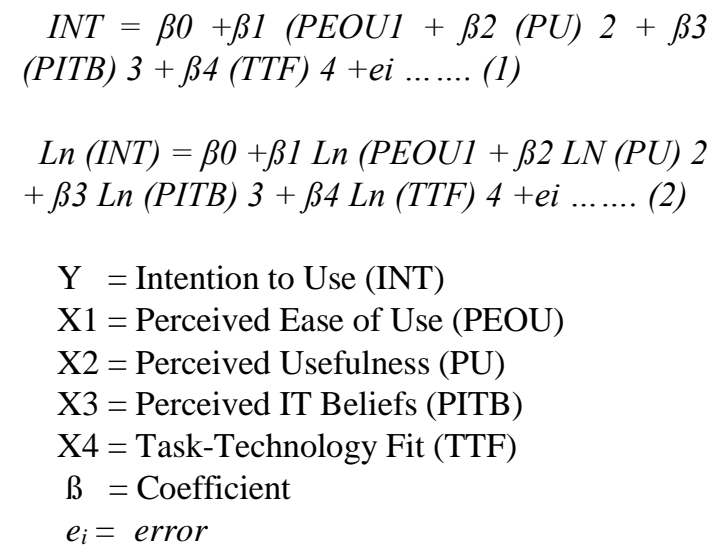

Hypothesis 1: Perceived Ease of Use (independent variable), Perceived Ease of Use has a positive significant influence on customers Intention in use of e-banking. Perceived Ease of Use in the Palestinian commercial banks and Islamic banks are measured by: the easiness of the system and convenience, the required details, and instructions on how to use the system, transfer money amonng accounts, the availability of information, and the system's policy to ensure 
that the system is secure. What has been noticed through measuring those factors, is that customers would like to make their transactions electronically rather than manually, and Hypothesis 2: Perceived Usefulness (independent variable), Perceived Usefulness has a positive significant influence on customer's Intention in the use of e-banking. The measure for this factor consists of: system's privacy which guarantees protecting the sensitive personal information that each customer has, design which makes customers to have an easy access into their accounts any time they want with no need to stick into queue. Moreover, system's design is also a customer friendly, and a technique that could be used to check transaction details and other statements regularly.

Hypothesis 3: Perceived IT Beliefs (independent variable), Perceived IT Beliefs has a positive significant influence on customer's Intention to use e-banking. Compatibility is seen as the capability of an innovation to be consistent with the person values, desires, and bygone experiences of potential adopters. Also, Trust affects the demand for e-banking services and consultations, high trust high customers. Therefore, IT beliefs has a deep relation with the system's security. Innovation has a direct relation as well to enhance IT beliefs, and the way that could attract as much customer as it could.

Hypothesis 4: Task-Technology Fit (independent variable), TTF has a positive significant influence on customer's intention to use e-banking. This variable has been measured by some sub-factors such as system's content, speed, and fees and

\section{RESULTS AND DISCUSSION}

The study findings were presented according to the research objectives as stated before. Therefore, our basic assumptions are that ebanking implementation and acceptance of technology have been measured by factors namely Perceived usefulness (PU), Perceived Ease of use (PEOU), Perceived IT Beliefs (PITB), and Task-Technology Fit (TTF)) influence traditionally as a belief that their accounts will be updated and arranged while they exist.

charges. Content has shown that clear and simple instructions that could help a wide range of customers, information credibility, it also shows that e-banking is increasingly upgraded compared to manual way. Speed has reflected a positive image about TTF, that's through saving time and effort, and you can easily connected to banks' channels smoothly and effectively. In addition, fees and charges are much cheaper and more acceptable than traditional banking. Thereby, Prices of installing new services' applications are reasonable and affordable, E-banks charge a symbolic fees on e-transactions, and the subscriptions fee is paid monthly in order to run financial services and other transactions.

Hypothesis 5: Intention to Use E-Banking (dependent variable), customer's intention has a positive influence on the usage of e-banking. Therefore, this intention was evaluated based on the customer's behavior and attitude. In other words, customers have a well-managed desire to adopt new service which could enable them to enjoy in carrying out a lot of transactions on the website. Moreover, during the analysis time, researchers have found out a good relationship among variables. Thus, this relationship has indicated that, this technology should be installed and offered in Palestinian's banks as soon as possible.

customer's intention namely behavior, and attitude. A multiple regression modeling approach is proposed as an effective method for studying the relationships among variables. Based on the statistical multiple regression model, the study has shown a great relation among factors and subfactors. Therefore, the research intends to describe the main content of this study to extract clear data, in which the content was described as follows: 
Table 1. Results - Perceived Ease of Use (PEOU) / (customer's Intention)

\begin{tabular}{|c|c|c|c|c|c|}
\hline $\begin{array}{c}\text { E-banking } \\
\text { factors }\end{array}$ & $\mathrm{R}_{2}$ & $\begin{array}{c}\text { Standardized } \\
\text { error }\end{array}$ & Beta & T-value & Significant \\
\hline $\begin{array}{c}\text { Perceived Ease } \\
\text { of Use (PEOU) }\end{array}$ & 0.423 & 0.654 & 0.556 & 3.864 & 0.0432 \\
\hline
\end{tabular}

The findings in table (1) provide significant support for the Perceived Ease of Use (PEOU) literature which advocates that PEOU had an influence upon Palestinian commercial-Islamic banks. Therefore, this factor has a positive impact on customer intention. These findings also comply with other research findings (for example, Davis, F. D. 1989; Daniel, E. 1999).

Table 2. Results - Perceived Usefulness (PU) / (customer's Intention)

\begin{tabular}{|c|c|c|c|c|c|}
\hline $\begin{array}{c}\text { E-banking } \\
\text { factors }\end{array}$ & $\mathrm{R}_{2}$ & $\begin{array}{c}\text { Standardized } \\
\text { error }\end{array}$ & $\mathrm{B}$ & T-value & Significant \\
\hline $\begin{array}{c}\text { Perceived } \\
\begin{array}{c}\text { Usefulness } \\
\text { (PU) }\end{array}\end{array}$ & 0.464 & 0.421 & 0.274 & 2.852 & 0.0344 \\
\hline
\end{tabular}

Perceived Usefulness (PU) is also considered to be one of the influential factors on the intention of Palestinian Commercial-Islamic banks (table 2). Prior research has empirically found positive relationship between PU and customer intention as critical factors on the use of e-banking (Tuchila, R. 2000; Jayawardhena, C., \& Foley, P. 2000).

Table 3. Results - Perceived IT Beliefs (PITB)/ (customer's Intention)

\begin{tabular}{|c|c|c|c|c|c|}
\hline $\begin{array}{c}\text { E-banking } \\
\text { factors }\end{array}$ & $\mathrm{R}_{2}$ & $\begin{array}{c}\text { Standardized } \\
\text { error }\end{array}$ & $\mathrm{B}$ & T-value & Significant \\
\hline $\begin{array}{c}\text { Perceived IT } \\
\text { Beliefs (PITB) }\end{array}$ & 0.389 & 0.312 & 0.289 & 2.023 & 0.000 \\
\hline
\end{tabular}

Perceived IT Beliefs (PITB) is also considered to be one of the influential factors on the intention of Palestinian Commercial-Islamic banks (table 3). Prior research has empirically found positive relationship between PITB and customer intention as critical factors on the use of e-banking (Daniel, E. 1999).

Table 4. Results - Task-Technology Fit (TTF)/ (customer's Intention)

\begin{tabular}{|c|c|c|c|c|c|}
\hline $\begin{array}{c}\text { E-banking } \\
\text { factors }\end{array}$ & $\mathrm{R}_{2}$ & $\begin{array}{c}\text { Standardized } \\
\text { error }\end{array}$ & $\mathrm{B}$ & T-value & Significant \\
\hline $\begin{array}{c}\text { Task- } \\
\begin{array}{c}\text { Technology Fit } \\
\text { (TTF) }\end{array}\end{array}$ & 0.399 & 0.386 & 0.203 & 2.318 & 0.000 \\
\hline
\end{tabular}

Task-Technology Fit (TTF) is also considered to be one of the influential factors on the intention of Palestinian Commercial-Islamic banks (table 4). Prior research has empirically found positive relationship between PITB and customer intention as critical factors on the use of e-banking (Goodhue, D. L., Klein, B. D., \& March, S. T. 1995). 
Table 5. Results - (customer's Intention)/ Behavior, and attitude

\begin{tabular}{|c|c|c|c|c|c|}
\hline $\begin{array}{c}\text { E-banking } \\
\text { factors }\end{array}$ & $\mathrm{R}_{2}$ & $\begin{array}{c}\text { Standardized } \\
\text { error }\end{array}$ & $\mathrm{B}$ & T-value & Significant \\
\hline $\begin{array}{c}\text { Intention to } \\
\text { Use (INT) }\end{array}$ & 0.467 & 0.052 & 0.282 & 2.792 & 0.004 \\
\hline
\end{tabular}

Table 6. Results - the implementation of e-banking (customer's intention)

\begin{tabular}{|c|c|c|c|c|c|}
\hline $\begin{array}{c}\text { E-banking } \\
\text { factors }\end{array}$ & $\mathrm{R}_{2}$ & $\begin{array}{c}\text { Standardized } \\
\text { error }\end{array}$ & $\mathrm{B}$ & T-value & Significant \\
\hline $\begin{array}{c}\text { E-banking } \\
\text { factors }\end{array}$ & 0.428 & 0.194 & 0.188 & 3.516 & 0.043 \\
\hline
\end{tabular}

$\mathrm{R} 2=0.428$ Adjusted R2 $=0.458 \quad \mathrm{~F}=14.432 \quad \mathrm{P}<0.05$

Based on the analysis, it was indicated that each factor is dramatically connected to one another. Thereby, it predicted that the influence of such factors (Perceived usefulness (PU), Perceived Ease of use (PEOU), Perceived IT Beliefs (PITB), and Task-Technology Fit (TTF) on intention of use would differ according to the personal variables, which are personal characteristics and their experience in computers (as shown in table of demographic characteristics). The results of the multiple regression analysis signal that there is variation in the effect of e-banking implementation factors on customer's intention and empirical evidence in this research suggests that e-banking factors have a significant degree of influence on this intention which was assessed by their behavior and attitude. This empirical evidence has provided significant support for the e-banking literature, which substantively advocates that e-banking implementation and acceptance of technology factors have an impact on customer intention. The results empirically substantiate that e-banking factors play a fundamental role in the intention of customers to adopt new technique among Palestinian commercial, and Islamic banks.

These results indicate that the Palestinian banks are an important element to facilitate a wide variety of users (managers, employees, and customers). Thereby, the using of e-banking is considered as reflective indictor which positively reflects a good perception, and insights into new online service sector (Palestinian banks), and it has positively influence the customer intention towards the use of e-banking. Other researches have empirically found positive relationship between e-banking and the implementation of ebanking.
Recommendations, based on the analysis of each factor, the study has come up with some important recommendations that must be taken into account. These recommendations are set as follows:

a. Developing plans and allocating the budgets to assist the banking sector in developing its electronic system, and services, and improving the performance of its operating process. In addition, working to reduce the higher costs, charges and fees resulted from the traditional use of banking sector. Thus, this could make Palestinian banks can push the economic situation towards gradual development in the state.

b. Working on enhancing the coordination between Palestinian banks and the world's new technology in order to make a substantial progress in its businesses.

c. Working on increasing the awareness of banks' customers to limit the usage of traditional banking methods, and adopt the idea of e-banking instead. The awareness could be obtained by conducting campaigns through the mass media and different publication methods.

d. Paying a serious attention to establishing and allocating funds for research and developmental technological administration which are required to keep the Palestinian banks informed of the latest technological techniques, systems, and procedures, and that is in order to minimize the higher costs, charges and fees, and make the whole transactions within a short period of time. 
Recommendation for further studies. This study was conducted in recognizing the implementation of E-banking and acceptance of technology in the State of Palestine hence it covered part or small area of Palestinian commercial-Islamic banks. Thus, another study is recommended in another

\section{CONCLUSIONS}

This study attempts to make contribution to knowledge by defining and analyzing the impact of e-banking factors on the attitude and intention of customers to use e-banking in Palestinian banks. This study contributes to the performance and precision of e-banking products and services in finding out the role of this system in enhancing customer intention and attitude. Factors pertaining to Perceived usefulness (PU), Perceived Ease of use (PEOU), Perceived IT Beliefs (PITB), and Task-Technology Fit (TTF) to be a focus of this study as they have a significant impact on customer intention, and attitude to use e-banking.

Contributions found will be beneficial for both academics and managers alike. Academically, this work aims to focus on academic attention upon a much neglected domain -information technology of banking services in Palestine. Currently there is a relatively dearth of literature on the implementation of e-banking system, especially which is related to Palestine, and other countries in the Middle East. This is somewhat surprising when considering that Palestine has been at the forefront of the banking services industry in the Middle East. The researchers found out that e-

\section{REFERENCES}

[1]. Alharbi, S., \& Drew, S. (2014). Using the technology acceptance model in understanding academics behavioural intention to use learning management systems. International Journal of Advanced Computer Science and Applications (IJACSA), 5(1): 1-13.

[2]. Allen, F., McAndrews, J., \& Strahan, P. (2001). E-finance: An introduction. Center for Financial Institutions Working Paper 01-36, Wharton School Center For Financial Institutions: University of Pennsylvannia. part for comparative purposes (For instance compare E-banking functionality of Palestinian banks with other banks in the Arab world) by depending on the given information of this research.

banking system will provide both of customers and employees with new technological technique connecting them online, and helps them make their financial transactions and other processes easily and conveniently rather than traditional banking methods. In addition, using e-banking technology is relatively new for the customers who have accounts in Palestinian banks. Thus, e-banking system will offer new ways to help these customers to save time and effort.

Finally, the conclusion is that there is a distinct need for e-banking technologies to be implemented in Palestinian banks, because it will facilitate a wide range of customers perfectly, and within a short period of time. Therefore, ebanking system is such an effective and efficient method that should be adopted and implemented in order to upgrade the level of quality and performance of those operating banks in Palestine.

Future research should also investigate whether the model could be applicable for being used for comparative purposes in order to distinguish between online service sector and non-online service sector. Therefore, through measuring and analyzing the differences and effects of electronic banking factors in both sectors, then it is easily to determine which one of these is good enough to serve a wide range of customers within short period of time.

[3]. Almasri, A. (2014). The influence on mobile learning based on Technology Acceptance Model (TAM), Mobile Readiness (MR) and Perceived Interaction (PI) for higher education students. International Journal of Technical Research and Applications, 2(1), 5-11.

[4]. Daniel, E. (1999). Provision of electronic banking in the UK and the Republic of Ireland. International Journal of Bank Marketing, 17(2), 7282. 
[5]. Davis, F. D. (1989). Perceived usefulness, perceived ease of use, and user acceptance of information technology. MIS Quarterly, 319-340.

[6]. DeYoung, R. (2001). The financial performance of pure play internet banks. Economic Perspectives, 25(1), 60-75.

[7]. Goodhue, D. L., Klein, B. D., \& March, S. T. (1995). User evaluations of IS as surrogates for objective performance. Information \& Management, 38(2), 87101.

[8]. Jayawardhena, C., \& Foley, P. (2000). Changes in the banking sector - The case of internet banking in the UK. Internet Research: Electronic Networking Applications and Policy, 10(1), 19-30.

[9]. Kazi, A. K., \& Mannan, M. A. (2013). An empirical study of factors influencing adoption of Internet banking among students of higher education: Evidence from Pakistan. International Journal of Finance \& Banking Studies, 2(2), 87-99.

[10]. Meshkany, F. A., \& Hashemi, R. (2013). EBanking: Status, implementation, challenges, opportunities. IOSR Journal Of Humanities And Social Science (IOSR-JHSS), 12(6), 40-48.

[11]. Nehmzow, C. (1997). The Internet will shake banking's medieval foundations. Journal of Internet Banking and Commerce, 2(2), 9702-9701.
[12]. Palestinian Central Burea of Statistic. (2018). Population in Palestine. Annual report.

[13]. Parhizgar, M. M., \& Poursaleh, P. (2014). Factors Affecting the Intention to Use Internet Banking Services, Journal of Sosial Issues \& Humanities, 2(3).

[14]. Pikkarainen, T., Pikkarainen, K., Karjaluoto, H., \& Pahnila, S. (2004). Consumer acceptance of online banking: An extension of the technology acceptance model. Internet Research, 14(3), 224235.

[15]. Pavlou, B., Rugimbana, R., \& Quazi, A. (2003). Differentiating between service quality and relationship quality in cyberspace. Managing Service Quality, 13(3), 217-232.

[16]. Proctor, R., Watson, G., \& Finger, G. (2003). Measuring information and communication technology (ICT) curiculum intregation. Computers in Schools, 20(4), 67-87.

[17]. Talla, J. H. N. (2013). An empirical study of e-banking in Cameroon [Master Dissertation], Pretoria: University oof South Africa.

[18]. Tuchilla, R. (2000). Servicii bancare prin internet. E-finance Romania, 3(3), 23 32. 
Table A. Demographic Characteristics of the Sample $(\mathrm{N}=84)$

\begin{tabular}{|c|c|c|}
\hline Characteristics & Frequency & Percent \\
\hline $\begin{array}{ll}\text { Gender: } & \\
& \text { Male } \\
& \text { Female }\end{array}$ & $\begin{array}{l}58 \\
26\end{array}$ & $\begin{array}{l}69.04 \\
30.95\end{array}$ \\
\hline 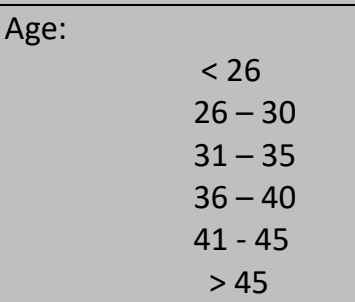 & $\begin{array}{c}9 \\
15 \\
18 \\
20 \\
12 \\
10\end{array}$ & $\begin{array}{l}10.71 \\
17.85 \\
21.42 \\
23.80 \\
14.28 \\
11.90\end{array}$ \\
\hline $\begin{aligned} \text { Computer Use: } & \\
& \text { Yes } \\
& \text { No }\end{aligned}$ & $\begin{array}{c}84 \\
---\end{array}$ & 100 \\
\hline $\begin{array}{l}\text { Internet Accessibility at } h \\
\text { office: } \\
\qquad \text { Yes } \\
\text { No }\end{array}$ & $\begin{array}{l}67 \\
14\end{array}$ & $\begin{array}{c}79.76 \\
16.6\end{array}$ \\
\hline
\end{tabular}

Figure A. Research model:

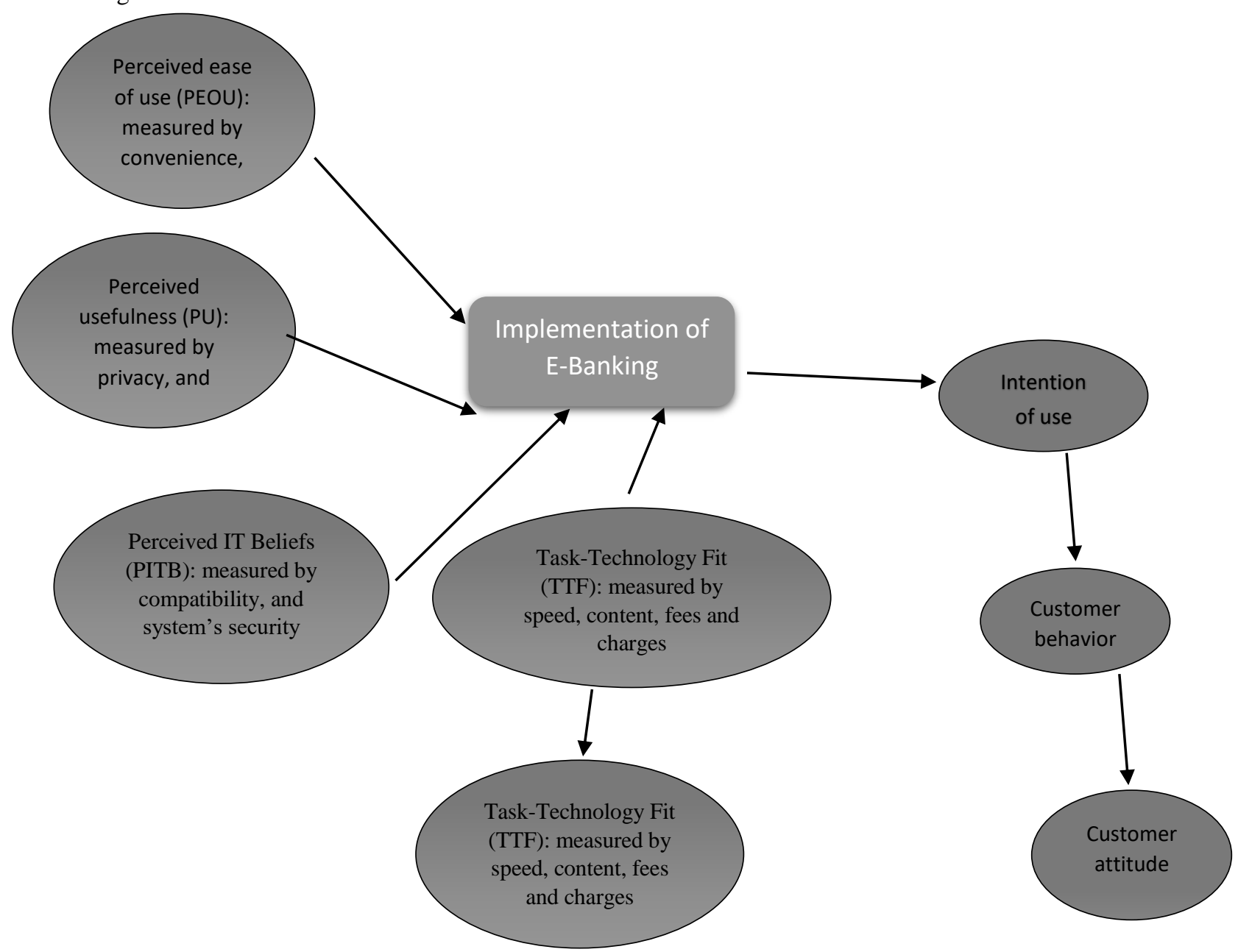

